\title{
NELAYAN SEBAGAI IDE PENCIPTAAN TARI TAREK PUKAT DALAM KAJIAN INTERAKSI SIMBOLIK
}

\author{
Fitriani \\ Program Pasca Sarjana, Universitas Negeri Semarang \\ E-mail: fitriani9347@gmail.com
}

\begin{abstract}
Abstrak
Tarek Pukat merupakan salah satu dari bentuk kesenian yang merupakan wujud kebudayaan hasil olah pikir, gagasan masyarakat pesisir Aceh. Tarek Pukat adalah gambaran aktivitas masyarakat pesisir yang memiliki rasa keindahan (estetika) yang ditimbulkan dari gerak, syair, dan musik. Setiap komponen terdapat kearifan lokal yang memiliki makna, isi pesan tentang norma-norma sosial, nilai-nilai budaya, dan sebagai wujud kebudayaan yang mengatur sistem sosial dalam menata aktivitas kehidupan sosial masyarakatnya. Interaksi simbolik lebih menekankan studinya tentang perilaku manusia pada hubungan interpersonal, bukan pada keseluruhan kelompok atau masyarakat. Proporsi paling mendasar dari interaksi simbolik adalah perilaku dan interaksi manusia itu dapat dibedakan, karena ditampilkan lewat simbol dan maknanya. Mencari makna dibalik yang sensual menjadi penting didalam interaksi simbolis. Tari Tarek Pukat ini difungsikan sebagai bentuk apresiasi terhadap budaya dan tradisi masyarakat Aceh pesisir, khususnya saat menangkap ikan di laut. Tarian ini dimaknai sebagai gambaran sikap gotong royong.
\end{abstract}

Kata Kunci: Tarek Pukat, Interaksi Simbolik

\section{FISHERMAN AS THE IDEA OF CREATION OF TAREK PUKAT DANCE IN SYMBOLIC INTERACTION STUDY}

\begin{abstract}
Tarek Pukat is one of arts which is formed of cultural thoughts, or ideas of coastal communities of Aceh. Tarek Pukat describes coastal community activities that have a sense of beauty (aesthetics) arising from motion, poetry, and music. Each component has a local wisdom that has a meaning, a message content about social norms, cultural values, and cultural forms that regulate the social life of the community. Symbolic interaction focuses more on the study of human behavior on interpersonal relationships, not on the whole group or society. The most fundamental proportion of symbolic interaction is that human behavior and interaction can be distinguished, because of events through symbols and their meaning. Seeking the meaning behind the sensuality becomes important in symbolic interaction. Tarek Pukat dance is functioned as a form of appreciation of the culture and traditions of coastal communities, especially when fishing in the sea. This dance is interpreted as a picture of mutual cooperation.
\end{abstract}

Keywords: Tarek Pukat, Symbolic Interaction

\section{PENDAHULUAN}

Provinsi Aceh terdiri dari 23 Kabupaten/ Kota-4 kabupaten dan 1 kota diantaranya tidak memiliki perairan laut, yakni Kabupaten
Aceh Tengah, Kabupaten Aceh Tenggara, Kabupaten Gayo Luwes, Kabupaten Bener Meriah dan Kota Subussalam. Selebihnya memiliki kawasan perairan laut yang dapat 
dijadikan sumber penghasilan masyarakat. Sumber Dinas Kelautan dan Perikanan Aceh memiliki kawasan laut dengan panjang garis pantai $16.000 \mathrm{~km}$, dengan luas perairan laut $295.370 \mathrm{~km}^{2}$ terdiri dari perairan teritorial dan perairan kepuluan seluas $56.563 \mathrm{~km}^{2}$ dan zona ekonomi eksklusif seluas $238.807 \mathrm{~km}^{2}$.

Laut adalah sumber kehidupan bagi masyarakat Aceh pesisir. Dari laut mereka menggantungkan harapan dan kebutuhan hidup mereka terpenuhi. Orang Aceh menyebut laut dengan sebutan laot atau disebut juga dengan pasie yang dapat digunakan oleh para nelayan untuk kegiatan menagkap ikan. Alat yang dipergunakan untuk menangkap ikan antara lain adalah jaring pukat. Pada umumnya orang menjadi nelayan berdasarkan turun temurun dari orang tuanya, para nelayan dapat dikatakan sebagai sebuah koloni yang mendiami wilayah sepanjang pesisir pantai.

Sosok Nelayan dengan pekerjaan yang keras turut mewarnai sikap dan prilaku individu yang bersifat keras dalam bermasyarakat disebabkan dari watak yang menjadi kebiasaan para Nelayan yang berkerja di atas dataran laut yang harus menggunakan tekanan suara yang keras. Dari keadaan yang dialami dalam kehidupan seharihari tidak mengherankan bila sikap dan tutur kata masyarakt pesisir Aceh terdengar interaksi dengan suara keras dan kasar. Masyarakat Aceh yang berbicara dengan suara keras dan kasar sering disamakan dengan prilaku awak meupukat lawak meulaot yang diartikan orang menjaring atau orang melaut. Interaksi dengan masyarakat lain di luar perkampungan mereka berlangsung secara normal dalam pergaulan sehari-hari, maupun dalam sosial budaya, dan adat istiadat.

Pola pikir dan gagasan yang diterapkan dalam peraturan dalam pranata sosial masyarakat pesisir Aceh ini tercermin dan dituangkan pada pepatah para orang tua di Aceh yang dikenal dengan ungkapan sebagai berikut: Adat bak potmeureuhom, hukom bak Syiah Kuala. Jika ditafsirkan maknanya "Peraturan adat ada di tangan raja, dan hukum ada di tangan ulama. Hal ini diperjelas dalam hadih madja (ungkapan adat) bahwa: "kanun bak putor phang, reusam bak laksamana" yang artinya: "peraturan keprotokolan atau reusam berada pada para raja atau laksamana." Dari pengertian yang disebutkan dalam ungkapan tersebut menjadi jelas bahwa semua kebiasaan yang dilakukan oleh masyarakat Aceh pesisir secara berulangulang dan terus menerus, itulah yang dinamakan reusam, sedangakan adat hukum yang tertulis. Di Aceh pada masa dahulu adat adalah keputusan dari poteumeruhom sebagai pimpinan eksekutif pemerintahan yang memuat peraturan-peraturan yang berlaku bagi semua kuala kerajaan maupun orang asing dalam tatanan sosial dan budaya.

Para leluhur dan tokoh adat Aceh menganggap pentingnya adat dan kearifan lokal dalam kehidupan sosial budaya dalam mengatur tatanan kehidupan masyarakatnya. Hal ini terlihat dalam beberapa syair Aceh dalam karya sastra dan musiknya sering mengungkapkan pepatah bahwa mate aneuk mepat jerat gadoh adat han meho mita yang artinya "mati anak jelas kuburnya, hilang adat ke mana di cari." Oleh sebab itu, pepatah ini dapat kita lihat di hampir setiap produk budaya masyarakat Aceh, khususnya di bidang seni tari dan musik seperti dalam bentuk Tarek Pukat.

Takari (2013: 164) mengemukakan bahwa kepercayaan masyarakat Aceh dalam tatanan sosial budaya menempatkan agama sebagai pilar kehidupan dan kebudayaanya. Giro (2001: 51) menjelaskan bahwa nilai kebudayaan merupakan konsep mengenai apa yang hidup dalam pikiran, apa yang dianggap bernilai, berharga dan penting dalam hidup, sehingga dapat berfungsi sebagai pedoman bagi warga masyarakat. Oleh karena itu, dalam setiap perilaku dan aturan kehidupan masyarakat Aceh selalu dikaitkan dengan nilai-nilai sosial budaya yang memiliki interaksi simbolik yaitu dapat berinteraksi satu sama lain bukan hanya melalui gerak isyarat tatapi juga melalui simbol signifikan.

Tarek Pukat merupakan salah satu dari bentuk kesenian yang merupakan wujud kebudayaan hasil olah pikir, ide ataupun gagasan masyarakat pesisir Aceh. Tarek Pukat sebagai gambaran aktivitas masyarakat pesisir yang memiliki rasa keindahan (estetika) yang ditimbulkan dari gerak, syair dan musik. Setiap komponen 
terdapat kearifan lokal yang memiliki makna, isi pesan tentang norma-norma sosial, nilai-nilai budaya dan sebagai wujud kebudayaan yang mengatur sistem sosial dalam menata aktivitas kehidupan sosial masyarakatnya.

Dalam bahasa Aceh, Tarek Pukat berarti menarik jala ikan. Kegiatan ini berlangsung di daerah pesisir, yang merupakan kegiatan rutin para nelayan. Kegiatan Tarek Pukat sangat kental akan kebudayaan Aceh karena Aceh di kelilingi oleh pesisir laut. Selain itu, Tarek Pukat merupakan sebuah tarian daerah yang menggambarkan tentang kegiatan menarek pukat Tarian ini diciptakan oleh almarhum Yusrizal Banda Aceh pada tahun 1962 (Burhan, 1986: 141). Tarek Pukat menggambarkan aktivitas para nelayan yang menangkap ikan di laut tarek berarti tarik sedangkan pukat adalah alat sejenis jaring yang digunakan untuk menangkap ikan (pemerintak kota banda Aceh, 2008). Tarian ini menggambarkan kehidupan para nelayan di pesisir aceh tersmasuk mebuat jaring dan mendayung perahu. Karakter gerakan ini dinamis dan ceria dengan iringan alat musik tradisional (Shofiana Fitri, 2009).

Tarian ini menceritakan kehidupan rakyat Aceh yang tinggal di pesisisr pantai yang sebagian besar bermata pencarian sebagai nelayan. Selain itu, tarian Tarek Pukat diiringi oleh musik serune kala serta tabuhan Gendrang dan Rapa 'i dengan alunan musiknya yang sangat tradisional dan kental akan kebudayaan Aceh. Tarian Tarek Pukat biasanya di tarikan oleh 7 sampai 9 orang perempuan dan 4 atau 5 orang laki-laki. Tarek Pukat mengandung makna simbolik. Sebagai gambaran, seluruh gerakan dalam tari ini dibawakan untuk berkerja sama dalam membuat pukat atau jaring yang menjadi simbol pada tarian ini. Pada dasarnya, gerakan tarian ini sangatlah sederhana, hanya saja dalam tarian ini mebutuhkan kekompakan dan fokus dalam gerakan duduk, karena dalam gerakan duduk itu yang menajdi proses pembuatan simbol pada tarian Tarek Pukat ini dimana para wanita berdiri dan duduk sambil merangkai rangkaian tali yang menyimbolkan jaring ikan, lalu para laki-laki mengiringi tarian ini di belakang para wanita dengan memperagakan gerakan yang mennyimbolkan seseorang menangkap ikan dan dan menyimbolkan gerakan mendayung perahu.

Hal ini mengisyaratkan bahwa adat merupakan pedoman yang bersifat abstrak, yang seharusnya tersimpan dalam pikiran anggota masyarakat Aceh. Bentuk-bentuk kesenian yang mempunyai ideology semacam ini hampir mempunyai kesamaan dengan daerah lain yang ada di Indonesia sebagai keberhasilan pengaruh budaya di Nusantara. Bagi masyarakat Aceh Tari Tarek Pukat ini juga difungsikan sebagai bentuk apresiasi terhadap budaya dan tradisi masyarakat Aceh pesisir, khususnya saat menangkap ikan di laut. Tarian ini dimaknai sebagai gambaran sikap gotong royong dan semangat kebersamaan masyarakat yang direfleksikan dalam sebuah tarian yang menjadi pemersatu dari setiap suku-suku yang mendiami Provinsi Aceh yang memiliki perbedaan baik dari segi suku, bahasa, adat istiadat, bahkan dengan berbagai kontur alamnya. Hal ini menunjukan fungsi integritas terhadap masyarakat di Aceh. Sebagai contoh, di Aceh ada beberapa suku etnik yang mendiaminya seperti Aceh Rayeuk, Gayo, Alas, Tamiang, Kluet, Aneuk Jamee, Singkil, Simeulue. Provinsi Aceh yang mempunyai adat dan bahasa yang berbeda, namun dengan semangat kebersamaan masyarakat Aceh melalui kebudayaan suku-suku yang ada di Aceh, manjadikan masyarakat Aceh bersatu dalam sistem kebudayaan keagaamaan yaitu agama Islam. Hal ini sangat berpengaruh terhadap perkembangan kesenian di Aceh khusunya seni tari dan musik.

Para leluhur dan tokoh adat Aceh (ulama) menganggap pentingnya adat dan kearifan lokal dalam kehidupan sosial budaya dalam mengatur tatanan kehidupan masyarakatnya. Hal ini terlihat dalam beberapa syair Aceh dalam karya sastra dan musiknya sering mengungkapkan pepatah bahwa "mate aneuk mepat jerat gadoh adat han meho mita" yang artinya "mati anak jelas kuburnya, hilang adat ke mana di cari." Oleh sebab itu, pepatah ini dapat kita lihat di hampir setiap produk budaya masyarakat Aceh, khususnya di bidang seni tari dan musik seperti dalam bentuk pertunjukan Tari Tarek Pukat 
Bentuk yang dipertunjukan dalam Tarek Pukat memiliki pesan dan gambaran tentang kesatuan dan kebersamaan masyarakat pesisir Aceh. bahwa kreativitas masyarakt aceh dalam membuat jaring ikan dengan berkerja sama saling menolong untuk mencari kebutuhan hidup masyarakat Aceh pesisir dapat dikatakan pula pertunjukan Tarek Pukat merupakan wujud representasi masyarakat Aceh. Mulai dari cara masyarakat Aceh dalam mengambil sebuah keputusan sampai wujud kekerabatan sesama masyarakat terdapat dalam pertunjukan Tarek Pukat. Akan tetapi, apakah masyarakat Aceh mengetahui simbol dan Makna yang terkandung dalam pertunjukan Tarek Pukat atau bahkan pesan yang terkandung dalam petunjukan Tarek Pukat sudah diserap dan menjadi bagian dari kehidupan masyarakat Aceh. Hal ini menjadi dasar pemikiran yang menginspirasi untuk penelusuran di dalam sebuah Interaksi Simbolik dalam Tarek Pukat.

Seperti yang dikemukakan oleh Mead (2012: 629) para interaksi simbolik cenderung menyetujui signifikansi kausal bagi interaksi sosial. Oleh karena itu, makna berasal bukan dari proses mental yang soliter tetapi dari interaksi. Fokus itu berasal dari pragmatisme Mead: dia berfokus pada tindakan manusia dan interaksi, bukan pada proses mental yang terisolasi. Para Interaksi simbolik secara umum menuruskanya di dalam arah ini, antara lain perhatian sentral bukan tentang bagaimana manusia menciptakan secara mental maknamakna dan simbol-simbol, tetapi bagaimana mereka mempelajarinya selama interaksi secara umum dan sosialisasi secara khusus.

Dikuatkan oleh Blumer (2012: 651) di sini Blumer mengikuti Mead (1934/1962), Blumer sering berargumen bahwa struktur-struktur bersekala besar tidak lebih dari sekedar kerangka kerja tempat terjadinya aspek-aspek kehidupan sosial yang benar-benar penting tindakan dan interaksi(1962/1969:87).

Bagaimana masyarakat Aceh berupaya menghidupkan dan memperkenalkan Tarek Pukat sebagai salah satu simbol dari aktivitas masyarakat Aceh pesisir dalam rangka mempresentasikan keadaan para nelayan dalam sebuah tarian tradisi masyarakat Aceh pesisir melalui acara-acara adat dan juga acara besar dalam ruang lingkup nasional maupun internasional. Inilah keterkaitan perbedaan antara tari tradisional Aceh pada umumnya dengan Tari Tarek Pukat yang mempunyai simbol yang berbeda pada tarian Aceh pada umumnya. Tarek Pukat sebagai jenis pertunjukan kreativitas di dalam unsur geraknya yang mengandung keunikan dalam gerak, karena adanya simbol dalam gerak Tarek Pukat yang menggambarkan proses pembuatan pukat atau jaring dalam tari dan menggambarkan peran dalam masyarakat pesisir Aceh yang bangga atas kesenian tradisional dan bagian dari kelompok yang ingin memperkenalkan kesenian dan kebudayaan yang dimilikinya.

Inilah yang menjadi dasar untuk mengungkapkan simbol dan makna dari Tari Tarek Pukat. Diharapkan setelah mengetahui simbol dan makna dari Tari Tarek Pukat dapat ditemukan nilai-nilai yang terkandung di dalamnya. Hal ini penting, karena dalam setiap kesenian tradisi terkandung pesan budaya yang disampaikan melalui pertunjukan. Dengan demikian, bisa ditemukan nilai-nilai budaya yang terkandung dalam pertunjukan Tarek Pukat yang menjadi simbol pada masyarakat pesisir Aceh.

\section{INTERAKSI SIMBOLIK}

Intraksionisme simbolik ini menjelaskan perbedaan antara teori ini dengan behaviorisme. Menurut Blumer istilah interaksionisme simbolik menunjukan sifat khas dari interaksi antar manusia, kekhasnya adalah bahwa manusia saling menerjemahkan dan saling mendenefisikan tindakanya bukan hanya sekedar reaksi belakang dari tindakan seorang terhadap orang lain. Tanggapan seseorang tidak dibuat secara langsung terhadap tindakan orang lain tetapi didasarkan atas "makna" yang di berikan terhadap tindakan orang lain itu. Interaksi antara individu, diantarai oleh penggunaan simbol-simbol, interpretasi atau dengan saling berusaha untuk saling memahami maksud dari tindakan masing-masing. Jadi dalam proses interaksi manusia itu bukan suatu proses di mana adanya stimulus secara otomatis dan 
langsung menimbulkan tanggapan atau respons. Menurut Teori Intraksionisme simbolik ini fakta sosial bukanlah merupakan barang suatu yang mengendalikan dan memaksakan tidakan manusia. Fakta sosial sebagai aspek yang memang penting dalam kehidupan masyarakat, ditempatkannya dalam kerangka simbol-simbol interaksi manusia.

Bagi Blumer (1969:2) interaksionisme simbolik bertumpu pada tiga premis:

1. Manusia bertindak terhadap sesuatu berdasarkan makna-makna yang ada pada sesuatu bagi mereka.

2. Makna tersebut berasal dari interaksi sosial seseorang dengan orang lain.

3. Makna-makna tersebut disempurnakan disaat proses interaksi sosial berlangsung.

Mead mengungkapkan manusia mempunyai sejumlah kemungkinan tindakan dan pemikiranya sebelum ia memulai tindakan yang sebenarnya dengan melalui pertimbangan. Karena itu, dalam tindakan manusia terdapat suatu proses mental yang tertutup yang mendahului proses tindakan yang sesungguhnya. Berpikir menurut Mead adalah suatu proses individu berinteraksi dengan dirinya sendiri dengan memilih dan menggunakan simbol-simbol yang bermakna. Melaui proses interaksi dengan dirinya sendiri itu, individu memilih mana di antara stimulus yang tertuju padanya akan ditanggapinya. Dengan demikian, individu tidak secara langsung menanggapi stimulus, tetapi terlebih dahulu memilih dan kemudian memutuskan stimulus yang akan ditanggapinya.

Simbol atau tanda yang diberikan oleh manusia dalam melakukan interaksi mempunyai makna-makna tertentu, sehingga dapat menimbulkan komunikasi. Menurut Mead, komunikasi secara murni baru terjadi bila masingmasing pihak tidak saja memberikan makna pada perilaku mereka sendiri, tetapi memahami atau berusaha memahami makna yang diberikan oleh pihak lain. Dalam hubungan ini, Habermas mengemukakan dua kecendrungan fungsional dalam argument bahasa dan komunikasi serta hubungan dengan perkembangan manusia. Pertama, bahwa manusia dapat mengarahkan orientasi perilaku mereka pada konsekuensi- konsekuensi yang paling positif. Kedua, sebagai kenyataan bahwa manusia terlibat dalam interaksi makna yang kompleks dengan orang yang lain, dapat memaksa mereka untuk cepat berinteraksi dengan apa yang diinginkankan orang lain.

Pada awal perkembangannya, interaksi simbolik lebih menekankan studinya tentang perilaku manusia pada hubungan interpersonal, bukan pada keseluruhan kelompok atau masyarakat. Proporsi paling mendasar dari interaksi simbolik adalah perilaku dan interaksi manusia itu dapat dibedakan, karena ditampilkan lewat symbol dan maknanya. Mencari makna dibalik yang sensual menjadi penting didalam interaksi simbolis. Secara umum, ada enam proporsi yang digunakan dalam konsep interaksi simbolik, yaitu;

1. Perilaku manusia mempunyai makna dibalik yang menggejala;

2. Pemaknaan manusia perlu dicari sumber pada ineraksi sosial manusia;

3. Masyarakat merupakan proses yang berkembang holistik, tak terpisah, tidak linear, tidak terduga;

4. Perilaku manusia itu berlaku berdasarkan berdasar penafsiran fenomenlogik, yaitu berlangsung atas maksud, pemaknaan, dan tujuan, bukan didasarkan atas proses mekanik dan otomatis.

5. Konsep mental manusia itu berkembang dialektik; dan

6. Perilaku manusia itu wajar dan konstruktif reaktif.

Mead bermaksud membedakan antara teori yang diperkenalkan dengan teori behaviorisme. Teori behaviorisme mempunyai pandangan bahwa perilaku individu adalah sesuatu yang didapat diamati, artinya mempelajari tingkah laku manusia secara objektif dari luar. Interaksionisme simbolik menurut Mead mempelajari tindakan social dengan mengunakan tehnik intropeksi untuk dapat mengetahui sesuatu yang dapat melatarbelakangi tindakan ssoial itu dari sudut actor. Jadi, interaksi simbolik memandang manusia bertindak bukan semata-mata karena stimulus dan respon, melainkan juga didasar atas makna yang diberikan terhadap tindakan tersebut. 
Menurut Mead, manusia mempunyai sejumlah kemungkinan tindakan dalam pemikiran sebelum ia memulai tindakan yang sebenarnya, seseorang terlebih dahulu berbagai alternatif tindakan itu melalui pertimbangan pemikirannya. Karena itu, dalam proses tindakan manusia terdapat suatu proses mental yang tertutup yang mendahului proses yang sebenarnya.

Perspektif tentang masyarakat yang menekan pada pentingnya bahasa dalam upaya saling memahami telah diungkapkan oleh Mead. Selanjutnya Blumer memperkenalkan sebagai premis interaksinisme simbolik sebagai berikut:

1. Manusia melakukan tindakan "sesuatu" berdasarkan makna yang dimiliki "sesuatu" tersebut untuk mereka;

2. Makna dari "sesuatu" tersebut berasal dari atau muncul dari interaksi social yang di alaminya seorang dengan sesamanya;

3. Makna-makna yang ditangani dimodifikasi melalui suatu proses interpretative yang digunakan orang dalam berhubungan dengan "sesuatu" yang ditemui.

\section{DESKRIPSI TARI TAREK PUKAT}

Tari Tarek Pukat adalah salah satu tarian tradisional yang berasal dari daerah Aceh. Tarian ini biasanya dibawakan oleh sekelompok penari wanita yang menari dengan menggunakan tali sebagai atribut menarinya. Tari Tarek Pukat ini merupakan tarian menggambarkan tentang aktivitas para nelayan Aceh saat menangkap ikan di laut. Tarian ini biasanya sering ditampilkan di berbagai acara seperti upacara penyambutan, acara adat, dan acara budaya.

Menurut sejarahnya, Tari Tarek Pukat terinspirasi dari tradisi menarek pukat atau tradisi menarik jala yang sering dilakukan oleh masyarakat Aceh, Khususnya masyarakat di daerah pesisir yang sebagian besar berprofesi sebagai nelayan. Konon kegiatan menarek pukat ini sudah dilakukan masyarakat pesisir Aceh sejak lama.

Saat menangkap ikan, mereka melepas dan menarik jala tersebut secara gotong royong. Setelah selesai menangkap ikan, hasil yang mereka dapatkan tadi akan dibagi-bagikan kepada warga yang ikut serta saat menarek pukat tadi.Tradisi tersebut kemudian direfleksikan dalam sebuah tari yang disebut dengan Tari Tarek Pukat ini.

Tari Tarek Pukat ini difungsikan sebagai bentuk apresiasi terhadap budaya dan tradisi masyarakat Aceh pesisir, khususnya saat menangkap ikan di laut. Tarian ini dimaknai sebagai gambaran sikap gotong royong dan semangat kebersamaan masyarakat yang direfleksikan dalam sebuah tarian.

Tari Tarek Pukat biasanya ditampilkan oleh para penari wanita. Jumlah penari tersebut terdiri dari 7 orang penari atau lebih. Jumlah penari biasanya disesuaikan dengan kelompok atau sanggar masing-masing. Dalam pertunjukannya, penari dibalut dengan busana tradisional serta dihias dengan hiasan dan tata rias yang membuatnya terlihat cantik. Dengan diiringi kelompok pengiring, penari menari dengan gerakannya yang khas dan menggunakan tali sebagai atribut menarinya.

Dalam pertunjukannya, Tari Tarek Pukat biasanya diawali dengan gerakan seperti tarian Aceh pada umumnya, yaitu menari dengan posisi duduk sambil menepuk dada dan paha. Gerakan tersebut dilakukan secara kompak mengikuti irama lagu dan musik pengiring. Setelah itu dilanjutkan dengan saling mengaitkan tali satu sama lain.

Salah satu hal yang menarik dalam tarian ini adalah di akhir tarian, ketika selesai mengaitkan tali satu sama lain, penari akan menarik tali tersebut dan menjadi sebuah rangkaian jaring/ jala. Bagi anda yang belum pernah menyaksikan tarian ini mungkin akan bingung, bagaimana cara mereka membuat jaring tersebut? Hal ini lah yang menjadi salah satu daya tarik Tari Tarek Pukat ini, dan tak jarang membuat para penonton takjub dan memberikan tepuk tangan yang meriah kepada para penari. Adapun nama gerak dalam Tarek Pukat yaitu: Surak (berteriak), Meulinggang (lenggang aceh), Meukayoh (mendayung), Peugot pukat (buat jaring), Tarek Pukat (tarik jaring ikan) 


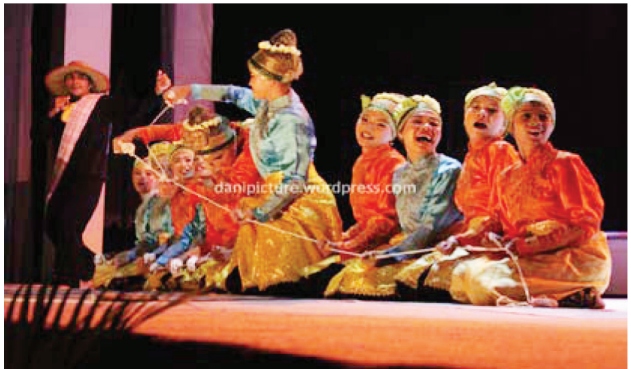

Gerak Peugot pukat

\section{Musik Pengiring}

Musik yang mengiring Tari Tarek Pukat yaitu karakter riang yang dihasilan dari alat musik pukul dan alat musik tiup. Alat musik pukul yang digunakan adalah rapai yaitu alkat musik tadisional aceh alat ini mempunyai karakter keras dengan suaranya yang mengehentak. Karakter musik sangat mendukung kesan riang dalam Tari Tarek Pukat ciri khas dari alat muski tradisional aceh dan alat tiup nya seurune kaleealat muski ini mempunyai karakter suara lembut dan mengalun yang dimaksudkan untuk menyeimbangi bunyi rapai yang menghentakhentak (Z.H. Idris, 1993: 47). Kemudian dinyanyikan oleh pengiring vocal. Namun, ada kalanya juga para penari menyanyikan beberapa bait lagu tersebut secara bersama sama. Saat menari, tempo gerakan penari juga harus disesuaikan dengan musik pengiring agar terlihat padu dan kompak.

Ureng meulaot ngoen ureng megoe

Piasan lagoe puncak utanam

Nyan khe pankai bagi kekaum

Udep lam nagroe makmu sedia

Kayoeh.......3x

Tarek pukat raken beh lambulen disepot

Karoe engkot jenara engkot jenara
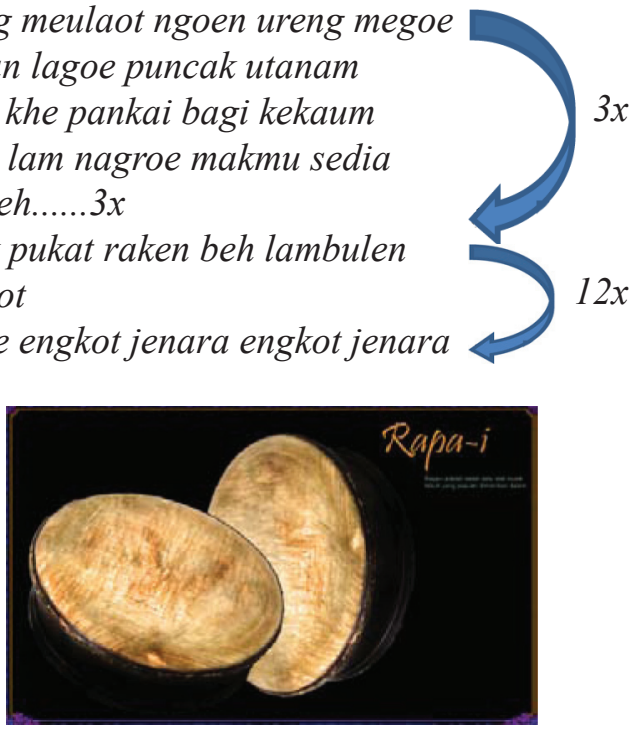

Rapa' $i$

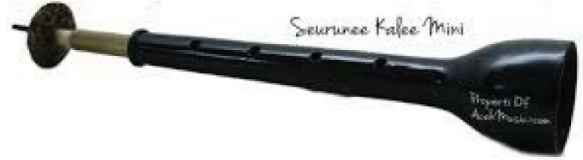

Seurunee kalee

2. Kostum Tari dan Properti Tarek Pukat

Kostum yang digunakan para penari dalam pertunjukan Tari Tarek Pukat ini biasanya merupakan busana tradisional. Para penari biasanya menggunakan pakaian seperti baju lengan panjang, celana panjang dan kerudung pada bagian kepala. Selain itu penari juga menggunakan kain songket dan sabuk pada bagian pinggang dan hiasan kerudung sebagai pemanisnya dan Alat yang digunakan dalam tarian ini yaitu, Topi yang terbuat dari rotan atau bambuTali panjang 1 meter
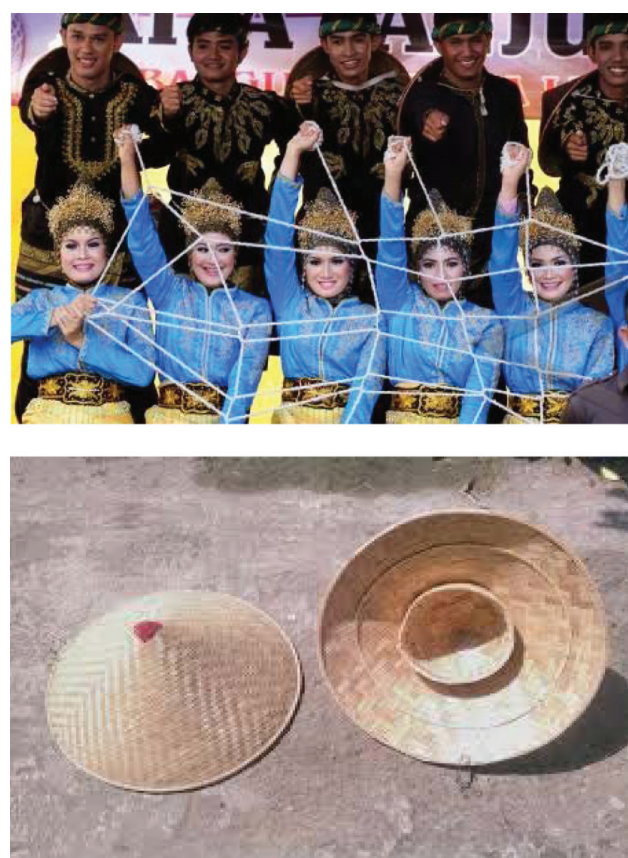

Topi Nelayan

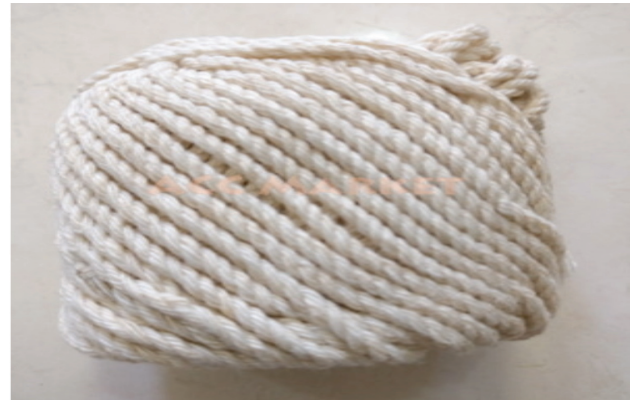

Tali 
Dalam perkembangannya, Tari Tarek Pukat masih terus dilestarikan dan dikembangkan hingga sekarang. Berbagai kreasi dan variasi dalam segi gerak, kostum, dan pengiring, juga sering ditampilkan di setiap pertunjukannya agar terlihat menarik. Walaupun begitu, namun tidak mengilangkan ciri khas dan keasliannya.

Tari Tarek Pukat juga masih sering ditampilkan di berbagai acara seperti acara penyambutan, acara perayaan dan acara adat lainnya. Selain itu, tarian ini juga sering ditampilkan di berbagai acara budaya seperti pertunjukan seni, festival budaya dan promosi pariwisata. Hal ini dilakukan sebagai usaha melestarikan dan memperkenalkan kepada generasi muda serta masyarakat luas akan Tari Tarek Pukat ini.

\section{INTERAKSI SIMBOLIK BERKAITAN TAREK PUKAT}

Tarian ini menceritakan tentang bagaimana kehidupan rakyat Aceh yang tinggal di pesisisr pantai, dimana sebagian besar bermata pencarian sebagai nelayan, Mengingat provinsi Nanggroe Aceh Darussalam sebagian besar di kelilingi oleh pesisir pantai, maka, tarian ini sangat mencerminkan keadaan orang-orang Aceh pesisir. Selain itu, tarian Tarek Pukat biasanya diiringi oleh musik "serune kala" serta Tabuhan Gendrang dan Rapa'i dimana alunan musiknya sangat tradisional dan kental akan kebudayaan Aceh sendiri. Tarian Tarek Pukat biasanya di tarikan oleh 7 sampai 9 orang wanita, dan 4 atau 5 orang laki-laki yang mengiringi tarian ini Tarek Pukat mengandung makna simbolik. Sebagai gambaran, seluruh gerakan dalam tari ini dibawakan untuk berkerja sama dalam membuat pukat atau jaring yang menjadi simbol pada tarian ini. Pada dasarnya, gerakan tarian ini sangatlah sederhana, hanya saja dalam tarian ini mebutuhkan kekompakan dan fokus dalam gerakan duduk, karena dalam gerakan duduk itu yang menajdi proses pembuatan simbol pada tarian tarreek pukat ini dimana para wanita berdiri dan duduk sambil merangkai rangkaian tali yang menyimbolkan jaring ikan, lalu para laki-laki mengiringi tarian ini di belakang para wanita dengan memperagakan gerakan yang menyimbolkan seseorang menangkap ikan dan dan menyimbolkan gerakan mendayung perahu.

Intraksionisme simbolik mengkaji dalam tiga konsep dalam Tarek Pukat untuk pemikiran yang mendasari interaksi simbolik yaitu:

1. Pentingnya makna bagi prilaku manusia dalam Tari Tarek Pukat

2. Didalam Tari Tarek Pukat ini membentuk makna bagi prilaku manusia, dimana dalam Tari Tarek Pukat ini tidak bisa dilepaskan dari proses komunikasi. Karena arti kata dalam Tarek Pukat yaitu menarik jaring ikan jadi sesuatu kegiatan yang dilakukan bersama-sama atau gotong royong. Sehingga menciptakan makna yang dapat disepakati secara bersama dan sebagai manusia bertindak terhadap manusia dengan menjalin kerja sama di dalam proses pembuatan pukat dalam masyarakat Aceh pesisir.Pentingnya konsep mengenai diri pada Tari Tarek Pukat

Tarek Pukat sebagai pengembangan konsep diri melalui individu tersebut secara aktif, didasarkan pada interaksi sosial dengan orang lainnya dengan cara antara lain : Individu-individu mengembangkan konsep diri melalui interaksi dengan orang lain, Konsep diri membentuk motif yang penting untuk perilaku.

3. Hubungan antara individu dengan masyarakat di dalam Tari Tarek Pukat

Tentang proses pemaknaan dalam Tari Tarek Pukat serta memahami gerak yang menajadi simbol-simbol pada Tarek Pukat tersebut. Melaui simbol-simbol pada gerak Tarek Pukat ini masyarakat berkemampuan untuk megetahui proses pembuatan pukat yang menjadi alat untuk mata pencarian masayarakat Aceh pesisir. Karena dalam Tari Tarek Pukat ini menggambarkan bagaimana proses pembuatan pukat atau jaring dan mencerminkan sifat saling kerja sama atau gotong royong untuk membuat alat menangkap ikan. Sehingga dapat menjalin komunikasi antara sesama dan menjadikan nilai-nilai sosial didalam kelompok masyarakat. 
Adapun Makna dari ragam gerak Tari Tarek Pukat yaitu:

1. Surak(berteriak)

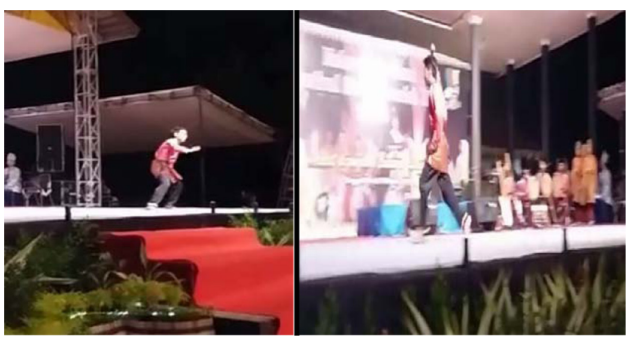

Didalam Tari Tarek Pukat ini surak berarti teriak yang bersimbol tentang semangat para nelayan untuk mencari ikan dilaut dan memberi tanda bahwa para nelayan ingin berlayar kelautan yang luas untuk mencari ikan dilaut dengan semangat teriakan "kayoh" berarti mendayung.

\section{Meulinggang (lenggang aceh)}

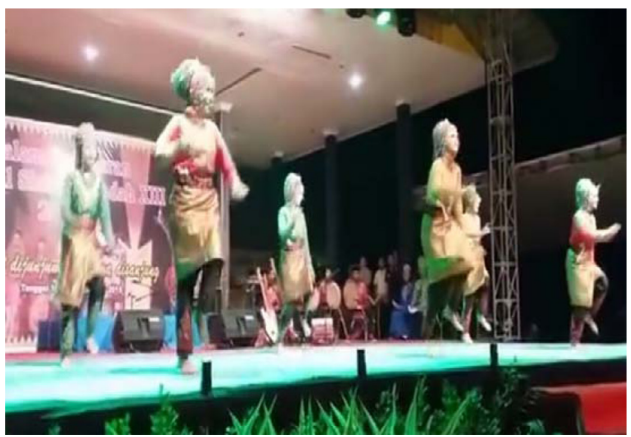

Meulinggang yang artinya berlenggang dalam gerak ini menggambarkan suasana kemeriahan dan kecerian masyarakat pesisir Aceh di dalam aktivitas untuk membuat pukat (jaring) yang dilakukan oleh para wanita Aceh.

\section{Meukayoh (mendayung)}

Gerakan kayoeh berarti mendayung dikonotasikan bahwa masyarakat aceh selalu berusaha untuk tetap mencari dan pantang menyerah untuk melewati ombak lautan. Gerakan kayoeh memberi pesan bahwa sifat dan karakter masyarakat aceh tidak pernah menyerah walaupun banyak rintangan yang dihadapi.

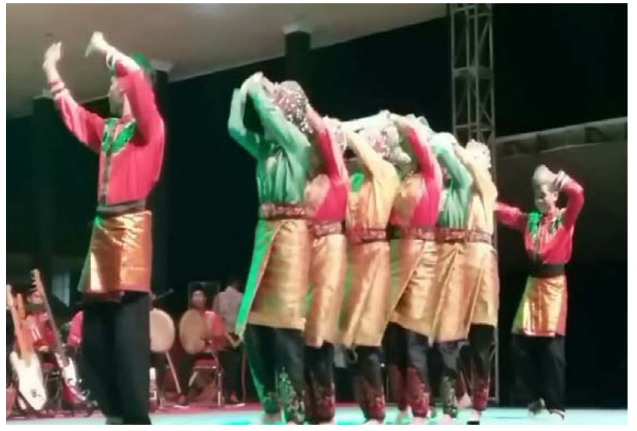

4. Peugot pukat (buat jaring)

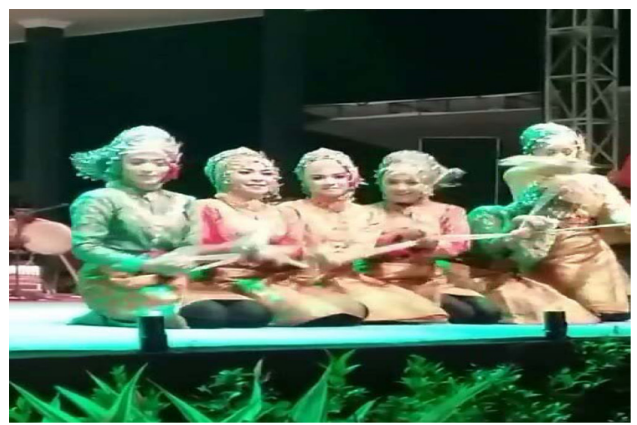

Gerakan Peugot pukat berarti membuat jaring ikan dikonotasikan bagi masyarakat aceh kegiatan ini menggambarkan kerja sama serta menjadikan alat untuk mata pencarian masyarakt pesisir aceh.

5. Tarek Pukat (tarik jaring ikan)

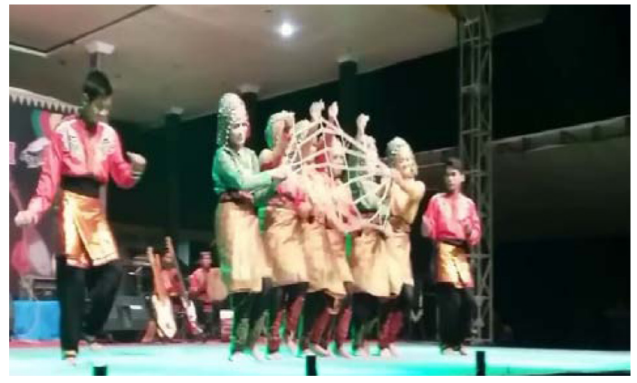

Gerakan Tarek Pukat berarti menarik jala ikan dikonotasikan bahwa masyarakat aceh selalu berkerja sama dalam kegiatan melaut makna menarik jala ikan yaitu menimbulkan kebersamaan dalam mendapatkan hasil dari ikan yang nyangkut di jaring. Gerakan Tarek Pukat memberi pesan bahwa masyarakat pesisir aceh selalu berkerja sama dalam kegiatan melaut 
yang sebagai mata pencarian masyarakat aceh pesisir.

\section{KESIMPULAN}

Simbol atau tanda yang diberikan oleh manusia dalam melakukan interaksi mempunyai makna-makna tertentu, sehingga dapat menimbulkan komunikasi. Didalam Tarek Pukat harus melakukan Interaksi sesama karena dalam bentuk tari ini menceritakan bagaimana aktivitas didalam masyarakat pesisir Aceh yang saling berkerjasama dalam berkegiatan membuat pukat dan menarek pukat hingga menjalin komunikasi. Tarek Pukat sebagai pengembangan konsep diri melalui individu tersebut secara aktif, didasarkan pada interaksi sosial dengan orang lainnya Melaui simbol-simbol pada gerak Tarek Pukat ini masyarakat berkemampuan untuk megetahui proses pembuatan pukat yang menjadi alat untuk mata pencarian masayarakat Aceh pesisir

\section{DAFTAR PUSTAKA}

Firdaus Burhan, ed. 1986. Ensikopedia Musik dan Tari Daerah, Propinsi Daerah Istimewa Aceh Banda Aceh: Pusat Penelitian Sejarah dan Budaya.

Lono Simatupang, 2013. Pergelaran (sebuah Moziak Penelitian Seni Budaya) Yogyakarta: Jalasutra Anggota IKPI

Pemerintah kota Banda Aceh, 2008. Seni Tari Aceh

Sofiana Fitri, 2009. Seni Budaya

Suwardi Endraswara, 2012. Metodologi Penelitian Kebudayaan. Yogyakarta: Gadjah Mada university Press

Wadiyo, 2008. Sisiologi Seni(Seni Pendekatan Multi Tafsir). Semarang: Universitas Negeri Semarang

Z.H. Idris, 1993. Peralatan Hiburan dan Kesenian tradisional propinsi daerah Istimewa Aceh. Jakarta: Proyek Penelitian, Pengkajian, dan Pembinaan Nilai-nilai Budaya. 